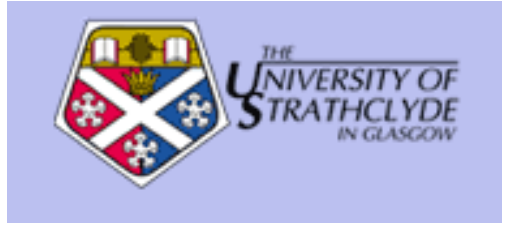

Connelly, Graham (2007) Can Scotland achieve more for looked after children? Adoption \& Fostering, 31 (1). pp. 81-91. ISSN 0308-5759

http://eprints.cdlr.strath.ac.uk/3363/

This is an author-produced version of a paper published in Adoption \& Fostering ISSN 0308-5759.

This version has been peer-reviewed, but does not include the final publisher proof corrections, published layout, or pagination.

Strathprints is designed to allow users to access the research output of the University of Strathclyde. Copyright (c) and Moral Rights for the papers on this site are retained by the individual authors and/or other copyright owners. Users may download and/or print one copy of any article(s) in Strathprints to facilitate their private study or for non-commercial research. You may not engage in further distribution of the material or use it for any profitmaking activities or any commercial gain. You may freely distribute the url (http://eprints.collr.strath.ac.uk) of the Strathprints website.

Any correspondence concerning this service should be sent to The Strathprints Administrator: eprints@cis.strath.ac.uk 


\section{Can Scotland achieve more for looked after children?}

Dr Graham Connelly

Senior Lecturer, University of Strathclyde

\section{Address for correspondence}

Dr Graham Connelly

Department of Educational and Professional Studies

University of Strathclyde

76 Southbrae Drive

Glasgow

G13 1PP

Scotland, UK

e: g.connelly@strath.ac.uk

t: +441419503131

m: +447770920267

f: +441419503129 


\section{Bio-notes}

Dr Graham Connelly is a chartered psychologist and senior lecturer in education at the University of Strathclyde, Glasgow, Scotland. He is also a trustee of Who Cares? Scotland.

\section{Key words:}

Looked after children, education, attainment, Scotland 


\section{Can Scotland achieve more for looked after children?}

\section{Summary}

The Learning with Care report (HMI and SWSI, 2001) made seven criticisms in relation to the provision of education for looked after children in Scotland. The most recent report, Looked after children \& young people: We can and must do better (Scottish Executive, 2007), contains 19 actions for improvement. This paper examines whether the distinctiveness of the Scottish political landscape has the potential to lead to improvements in tackling the deficits in the educational experience and attainment of looked after children and young people clearly acknowledged by the authors of both reports. The paper considers the recent history of political concern and asks whether things are getting better, concluding that while there is only limited improvement, the climate is more supportive and more emphatic in its expectations of the young people and the professionals who support them. 


\section{Introduction}

In a recent issue of this journal, Hare and Bullock (2006) reviewed two major reports critical of the current situation in relation to looked after children in England (Sergeant, 2006 and DfES, 2006). In their paper, Hare and Bullock welcomed the challenge to 'comfortable professionals and politicians' represented by the hard-hitting portrayal of poor outcomes in many areas of the lives of looked after children. However, as an academic committed to raising awareness and developing professional practice in relation to the educational needs of looked after children, I was particularly struck by the warning sounded in the authors' conclusion.

But if this shock therapy fails to work, there is a danger that the tone ... will merely reinforce negative stereotypes of looked after children that not only insult them as individuals but also make it virtually impossible for them to make their way in the world (ibid., p 35).

It seems important to keep this warning in mind when undertaking an examination of the current situation in relation to the education of looked after children in Scotland, where in the last few months two important reports have been published. The Social Work Inspection Agency's report Extraordinary Lives (SWIA, 2006) sets an optimistic tone in the choice of words used in its sub-title - 'creating a positive future' - and a chapter on education bears the title, 'achieving children'. The main report is supported by a series of four more focused reports, one of which is a study of 30 adults and young people 'whose experience of being looked after has been positive and life enhancing' (Happer, McCreadie and Aldgate, 2006, p 
1). The second report, and the main focus of this paper, Looked after children \& young people: We can and must do better, is the product of six months' deliberations by a working group which included three Scottish Executive ministers, civil servants, professionals, a foster carer and a care leaver (Scottish Executive, 2007). The report sets out 19 actions, some of which have appeared before in different forms. What makes this report stand out among typically dry government documents, however, is the rather refreshing way in which the views and questions of the working group are set out to provide a context for the actions specified.

The aim of this paper is to discuss that context, with reference to the education of looked after children and young people, and to consider whether the distinctiveness of the Scottish political landscape has the potential to lead to improvements in tackling the substantive issues. The starting point in this analysis, therefore, is an understanding of the political and legal contexts.

\section{The Scottish political and legal contexts}

The UK in the $21^{\text {st }}$ Century is, according to different viewpoints, either accommodating or struggling to adjust to the constitutional, political and practical implications of devolved government. At the time of writing, the $300^{\text {th }}$ anniversary of the union of the Scottish and English parliaments in 1707 had just been celebrated, albeit in rather low-key fashion with elections for the third administration in Edinburgh since the Scottish Parliament was reestablished in June 1999 just over three months away. The Parliament has the power to raise 
limited taxes (though so far not exercised) and has substantial legislative responsibilities, including the key welfare areas of health, education and social services. The legislators have been busy; in these three areas alone, they passed no fewer than 26 acts between 2000 and 2006. There have been two particular effects of legislative devolution. The first is the possibility of quite different imperatives emerging in the constituent countries of the UK. The best known consequences in relation to Scotland, arising partly from the virtually inevitable coalitions produced by the voting system, are the provision of free nursing and personal care for those aged over 65 living at home, and the total ban on smoking in enclosed public places. The second effect is that the main business of Scottish politics invariably centres on the devolved responsibilities and these, as a consequence, are subject to in-depth analysis by journalists. For example, the report Looked after children \& young people: We can and must do better was the first or second-lead item on every BBC Scotland bulletin on the day it was launched.

Hare and Bullock argue that there has been a consensus in government in the UK which has served to keep the welfare of disadvantaged children out of party political arguments, and that as a consequence major reforms 'were passed with minor amendments rather than radical disagreements and knife-edge votes' (ibid., p 26). The prominence of the committee system in the functioning of the Scottish Parliament was designed to facilitate consensus, a fact that potentially makes the legislature more compliant. However, the backgrounds of the politicians themselves may help them to be more quietly effective law makers and shakers. MSPs, in contrast to their Westminster counterparts, are more likely to be drawn from professional middle class backgrounds, with a greater tendency for Labour MSPs to have worked in public sector occupations (Keating and Cairney, 2006). In other words, there is a greater likelihood 
in Holyrood than Westminster that the legislators will have direct professional knowledge of the issues being debated. This does not mean that MSPs will always make sound decisions, or be any less susceptible to party whipping than their Westminster colleagues. But they do at least have ready access to professional networks, freeing them from complete reliance on the advice of career civil servants, and they are generally well placed to ask pertinent questions. Before considering the political context specifically in relation to the education of looked after children, it is important to be clear about the distinctive meaning of the term 'looked after' as used in Scots law ${ }^{1}$.

The drafters of the Children (Scotland) Act 1995 adopted the term 'looked after' from the earlier Children Act 1989 in England and Wales, and also for the same reasons. The term 'in care' had become a rather pejorative description, while the preferred term 'looked after' emphasised the corporate responsibilities of the local authority to provide additional support for families. Unlike the position in England and Wales, local authorities in Scotland do not automatically acquire parental responsibilities when a child becomes subject to compulsory ${ }^{2}$ measures of supervision, though they do have considerable discretion in determining the nature of intervention. The uniqueness of the Children's Hearing system, established by the Social Work (Scotland) Act 1968, means that a child's care and protection takes primacy over juvenile justice, though the growing tendency to emphasise anti-social behaviour among adolescents has been straining the liberal consensus in dealing supportively with child offenders in Scotland as elsewhere in the UK. In Scotland, a child under compulsory measures of supervision can be looked after by the local authority while continuing to live

\footnotetext{
${ }^{1}$ See McRae (2006) for more information about the legal framework which supports the care of looked after children and young people in Scotland.

${ }^{2}$ Compulsory in this context means that a children's hearing or court has stipulated care requirements.
} 
with family. The 'at home' category accounted for $43 \%$ of the 12,966 children who were looked after by local authorities in Scotland on 31 March 2006, and this group includes both children living with parents or with extended family or friends (kinship care). These looked after children are arguably the most vulnerable and least supported. The Learning with Care report (HMI and SWSI, 2001) dealt only with children provided with accommodation, and perhaps as a result local authority measures aimed at raising the attainment of looked after children are often targeted solely at children in residential and foster care, therefore children in the 'at home' category can slip below the radar. Schools are often unclear about their corporate responsibilities to pupils in the at home category. And yet the attainment of those looked after at home is the poorest among all looked after children ${ }^{3}$. A recent study of kinship care suggests that children looked after by relatives and family friends are particularly affected by financial hardship (Aldgate and McIntosh, 2006). There is no separate leaving care legislation in Scotland, though the provisions for social security benefits of the Children (Leaving Care) 2000 Act in England and Wales apply equally to Scotland since treasury functions are reserved to the UK government. While the Regulation of Care (Scotland) Act 2001 strengthened the legal requirements for local authorities to conduct assessments of and provide support for young people leaving care, it is the case that a high proportion of young people in Scotland feel abandoned on leaving care (Dixon and Stein, 2002). As this paper was in preparation, the Scottish Executive announced $£ 25$ million of funding to support looked after children to continue education beyond age 16 or to gain employment, though the details of the scheme were not available.

\footnotetext{
${ }^{3}$ For detailed statistical information about looked after children in Scotland see: http://www.scotland.gov.uk/Publications/2006/12/08105227/0.
} 


\section{The recent history of political concern}

In common with other parts of the UK, concern has been expressed in Scotland about the educational experiences and outcomes of looked after children for at least 15 years. However, significant political and professional interest in Scotland dates to the appearance of two key publications. Borland et al. (1998) published a review of research, policy and practice in the education of looked after children which, in turn, helped to inform a report of a joint inspection of the experiences of children looked after away from home (HMI and SWSI, 2001). The Learning with Care report was based on a small sample of 50 and examined only the circumstances of children and young people provided with accommodation. It did have a number of positive findings, but it was inevitably the inspectors' seven main criticisms (listed below) that became the benchmarks against which subsequent improvements would be measured $^{4}$.

1) Limited planning of care and placements and vagueness about children's attainments.

2) High levels of exclusion (half the children and young people had been excluded at least once and some had been excluded many times).

3) Just over half of the 25 primary age children were underachieving in comparison with their peers.

4) Concern by children and young people about how confidential information would be used by teachers.

5) Lack of training concerning the education of looked after children and young people of carers, social workers and teachers.

\footnotetext{
${ }^{4}$ For a fuller discussion of the report, see Maclean and Gunion (2003).
} 
6) Lack of involvement of natural parents in the education of their children.

7) Little evidence of local authority policies on the education of looked after children and young people or of arrangements to collect data about their attainments.

Following the publication of the report, expressions of concern gathered pace and the direct involvement of senior government ministers was evident in a number of significant announcements. In October 2001 the then Education Minister, Jack McConnell, a former teacher, announced the distribution of a one-off fund of $£ 10 \mathrm{~m}$ to be paid to local authorities in financial year 2001-2002. The fund, 'based on $£ 500$ per child looked after in a family home and $£ 2,500$ for looked after children and young people in local authority or independent homes, or in residential or secure accommodation', was intended 'to provide books, equipment and homework materials for every looked after child in Scotland' (Scottish Executive, 2001). Despite a general welcome for the additional funding, there were also criticisms. The grant was short-term, expenditure had to be approved and spent in around 10 weeks and the capital investment left local authorities with responsibilities to fund future maintenance and replacement. A report by Who Cares? Scotland (O'Hagan, 2003) indicated that of 170 young people surveyed, 98 (58\%) were unaware that money had recently been invested in their educational attainment, and also that few $(22 \%)$ had been given a say in the spending. Among other criticisms expressed, some young people were disappointed that the expenditure did not appear to benefit them directly.

In January 2002 McConnell's successor, former social worker Cathy Jamieson, announced three priorities for action by local authorities, based on recommendations in the Learning with Care report. 
All looked after children should receive full-time education. We expect no less for our own children.

All looked after children should have a care plan which adequately addresses educational needs. This is a statutory obligation and has been since 1997.

All schools should have a teacher designated to championing the interests of these children (Scottish Executive, 2002).

The Minister also announced the commissioning of work to develop information and training materials aimed at carers, social workers and teachers and quality indicators for auditing the provision of education for looked after children ${ }^{5}$. One year later, the Minister acknowledged progress in relation to the targets she had previously identified, but firmly pointed to the need for further action.

Access to education is a basic right for every child. Too many of those cared for by local authorities are still being let down. They are being denied the same chances as other children. It is not acceptable that six out of ten young people leaving care at 16 and 17 are doing so without any qualifications (Scottish Executive, 2003).

In October 2004, then Deputy Education Minister, Euan Robson, another former teacher turned politician, announced funding of $£ 6 \mathrm{~m}$ for pilot projects: ‘...to explore new ways of boosting educational attainment' (Scottish Executive, 2004). The aim of the pilot funding for projects was to identify practices shown to lead directly to improved experience of education

\footnotetext{
${ }^{5}$ The development process is described in Furnivall and Hudson (2003) and Connelly (2003).

The information booklet is available online at: http://www.hmie.gov.uk/documents/publication/5679text.pdf. The training materials are available online at: http://www.hmie.gov.uk/documents/publication/LWC\%20Training\%20Materials.pdf. The quality indicators are available online at: http://www.hmie.gov.uk/documents/publication/hgioslac.pdf.
} 
and therefore higher attainment. It was hoped that this experience would help all local authorities to institute more positive practices. A total of 18 local authorities received funding for a range of pilot projects between 2005 and 2007 and research commissioned by the Scottish Executive to examine the effectiveness of the interventions employed by the projects is due to report in 2008 .

The account of activity described above demonstrates a significant degree of political commitment to improving the educational attainment of looked after children and young people in Scotland. The activity described, and the related developments not outlined here, also represent the laying down of an infrastructure for improvement. The government is clearly taking its responsibility for monitoring developments very seriously and Looked after children \& young people: We can and must do better announced the appointment of a senior executive (swiftly in post within days of the report's launch) to:

...work closely with Chief Executives and Senior Officials within each local authority. $\mathrm{He} /$ she will discuss what is being done to improve educational outcomes for looked after children and young people and care leavers with the relevant corporate parents and will provide reports twice a year to Cabinet (ibid., p 12).

However, political timeframes are short and ministers reporting to Parliament want to be able to see a quick return for their financial investment. Is there any evidence already of improvements in the educational experience and attainments of looked after children, and in the landscape of services which support them? 


\section{Are things getting better?}

This is a very reasonable question to ask, though a much more difficult one to answer without the cautions and caveats that frustrate politicians and journalists. In what follows, the question is addressed using some of the seven benchmarks outlined above as a guide for discussion.

Reporting in Learning with Care in 2001, the inspectors said they found evidence of limited planning of care and placements, and vagueness about children's attainments (see criticism 1), and little evidence of arrangements to collect data about their attainments (see criticism 7). The most publicly visible indicator of the attainment of looked after children in Scotland is the information about the qualifications of 16 and 17 year-olds leaving care in the previous year which have been included in the annual looked after children statistics since year ending March 2002. These statistics tell a similarly bleak story to that emerging from attainment data elsewhere in the UK, though there have been small percentage gains in the years since 200304 (see Table 1). Professionals complain that these statistics unfairly represent the supportive work of agencies and also diminish the future potential of young people who may flourish later as a result of contact with leaving care projects and further education colleges. Hare and Bullock (ibid.) also provide a detailed account of six 'cautions' to be considered in drawing conclusions from empirical findings of this sort. But it is the story behind the statistics in Table 1 that is revealing. Two local authorities in Scotland were unable to provide any information in time to be included in the statistical report and many of the tables have cautionary notes about missing information. There are also doubts about the accuracy of some of the information provided and, in particular, it is known that attainment data for a significant proportion of looked after children are not recorded in this return. Information about young 
people looked after at home is thought to be especially fragile in this respect, and, as a consequence, the extent of the disparity in attainment apparent between this group and those looked after away from home needs to be treated with caution. The fragility of the national data points to continuing difficulties in recording and sharing information within local authorities and between agencies. A school manager told me that she did not know which children in her school were looked after because a social worker had insisted this information was confidential. Information about attainment was requested retrospectively but its value in planning for the child's development was negated. An anecdote is not robust evidence but it does serve to illustrate concerns I still hear more widely expressed.

[Table 1 about here]

Lack of planning in relation to education was an important observation emerging from earlier studies in England and Scotland (e.g. Bullock, Little and Millham, 1993; Francis, Thomson and Mills, 1996). The immediate problem in attempting to judge whether there is evidence of improvement is the lack of data from a consistent sample at two points in time.

A detailed study of the use of care plans was conducted for the Scottish Executive by researchers led by Vincent in 2004 . The research used an audit questionnaire administered by 29 of Scotland's 32 local authorities in relation to the Looking After Children materials. The files of 430 accommodated children and young people were audited. The 'Essential Core Record and Placement Agreement' form holds all the personal information about the child, including education, medical and contact details. The auditors found that educational information was fully completed in over $66 \%$ of cases and nearly completed in a further $12 \%$ 
of cases. However, in relation to the provision of more detailed information, Vincent's report is rather less encouraging. The 'Essential Background Record' should provide more comprehensive information about the child, but the audit showed that educational information was fully completed in only $37 \%$ of cases, nearly completed in a further $17 \%$ of cases, only partially or minimally completed in $21 \%$ of cases and not completed at all in $23 \%$ of cases. Further analysis by the researchers highlighted problems in sharing information between social work and education agencies and, in some cases, they found evidence that agreed protocols for exchanging information within authorities had not been implemented. The audit showed that although most files had a completed 'Care Plan' and that plans were generally good, a quarter had none. A similar picture of incomplete information and lack of attention to educational aspects of the child's life was found in audits of the 'Day-to-Day Placement Arrangements Record' and of the 'Assessment and Action Records'. Thus, we are not in a position yet to judge whether things have got better but we do know that in the very recent past the practice of recording and sharing of information needed to improve significantly. Since the forms are not used in relation to the looked after at home category, a significant proportion of looked after children drop below the reporting radar.

The 2007 report Looked after children \& young people: We can and must do better acknowledges the extent of a problem which has been very resistant to improvement and proposes that, at least in part, the solution lies in proposals previously announced in the report Getting it right for every child (Scottish Executive, 2005a). A draft bill ${ }^{6}$ currently before Parliament includes proposals for a single assessment, record and plan to be used by all agencies working with children, with the aim that action plans should be in place by

\footnotetext{
${ }^{6}$ A report of consultation, including the draft bill, was published in December 2006. See: http://www.scotland.gov.uk/Publications/2006/12/18140606/0.
} 
December 2007 for all children going to a children's hearing. The idea is to streamline the bureaucracy while improving efficiency. Another measure proposed is to have a lead professional appointed in each case, with the responsibility to co-ordinate collaboration between agencies.

Learning with Care reported high levels of exclusion from school among the sample of looked after children studied (see criticism 2). In 2005-06, while the rate of exclusion in Scotland for children not looked after was 55 per thousand, 337 per thousand looked after children were excluded from school. The official statistics show that pupils registered for free school meals, pupils with additional support needs, and looked after pupils, all had higher exclusion rates than other pupils. Where a pupil had all three of these factors the exclusion rate was 15 times that of pupils with none of them. Virtually all exclusions are for short periods (typically less than one week) and in over $70 \%$ of cases the precipitating reasons include persistent disobedience, verbal abuse of staff and offensive behaviour. Table 2 shows the pattern of exclusion of looked after children over a period of seven years. The most visible feature is that schools' tolerance of challenging behaviour appears to have been declining, or at least the willingness of teachers to manage difficulties within the school seems to have tailed off in recent years. The explanation for the lower rates of exclusions of looked after children in 2000-01 and 2001-02 was the introduction of national targets for the reduction of exclusions generally. These were later withdrawn amid high profile protests from teachers' organisations. What this picture indicates is that while there are increasing efforts to improve the educational experience and to raise the attainments of looked after children, the same degree of effort is clearly not being put into achieving a reduction in the exclusion statistics. This is an acknowledged area of tension, with a high proportion of teachers apparently in 
favour of exclusion as an answer to disruptive pupils (Adams, 2005). However, it is not clear that local authorities have been able to make effective provision for alternatives to mainstream education; if rates of exclusion of looked after children are to continue at such high levels, planning for credible alternative educational provision must be given higher priority. Looked after children also have lower school attendance rates, although those looked after away from home have attendance rates less than $2 \%$ lower than those for non-looked after children, a testament to the success of foster and residential carers in ensuring children attend school.

[Table 2 about here]

The review group whose deliberations are reported in Looked after children \& young people: We can and must do better expressed shock at the high rates of exclusion, noting:

...whilst it is important that head teachers retain the right to exclude disruptive pupils, schools also need to be aware of the many challenges and obstacles looked after children and young people face... (ibid., p 23).

Nevertheless, it is not entirely clear how this expression of shock will translate into a change in the trend toward increasing exclusions, though a clue to the group's thinking about this lies in their pleas for more sensitivity to the needs of looked after children, and their observation that while the requirement of every school to have a 'designated senior manager' with specific responsibility for looked after children is now in place, 'there is still a great deal of variation as to how the role is both defined and carried out across Scotland' (ibid., p 21). 
The group's approach is more carrot than stick: a list of core tasks and a 'practical toolkit' for designated senior managers will be commissioned; and:

We will improve training for parents, foster carers, residential workers, teachers including teachers in training - social workers, health visitors and appointed lead professionals (ibid., p 15).

As outlined above, training materials were prepared in the two years following the publication of the Learning with Care report (see criticism 5). So does the most recent strategy have any more likelihood of success? That is difficult to call. Certainly the climate is different this time, both in terms of policy and practice. The strategy (itself considerably more detailed than the 2001 report's recommendations) has visibly stronger political backing, and no one is suggesting that this will vanish if the complexion of the government changes following the May 2007 Scottish general election. Press interest is also noticeably greater, and not just confined to the professional journals. Finally, the infrastructure of key official bodies (e.g. the Convention of Scottish Local Authorities and Learning and Teaching Scotland) and professional networks (e.g. LAC Education Network, LAC Nurses' Network and LAC Psychologists' Network) is both more comprehensive and more integrated.

The language used in the 2007 report is more mandatory than permissive in tone, with, for example, the words 'we will ensure' heading the paragraphs outlining the responsibilities of the Scottish Institute of Residential Child Care to embed children's education within their training courses for residential workers, and for directors of initial teacher education courses to give priority to the needs of looked after children when planning course content. The 
ministerial review group was critical of the fact that teachers and social workers train separately. Behind this point lies an interesting set of discussions still to be had in relation to assumptions about the traditions in Scotland in respect of professional training for teachers, social workers and community educators. There are practical considerations, of course, such as the differing requirements of professional accrediting bodies, but are these simply excuses for inaction?

The authors of Learning with Care found little evidence of local authority policies on the education of looked after children (see criticism 7), while Looked after children \& young people: We can and must do better noted confidently that: 'All authorities have either developed or revised joint policies and protocols...' ( $(\mathrm{p} 9)$, providing clear evidence of improvement. However, despite the development of quality indicators for auditing schools and care settings following Learning with Care, there has been little evidence of impact so far. In my own, unpublished, survey of a group of schools in a single learning community (one high school and its related primary schools and pre-school centres), I found none had used the quality indicators, despite the materials having been in the schools concerned for three years. This begs the question: why should we expect schools to pay any more attention to the latest report?

\section{Conclusion}

This paper began with the intention of considering whether the distinctiveness of the Scottish political landscape has the potential to lead to improvements in the education of looked after 
children and young people. There are at least three propositions contained within this brief consideration. The first is that any subsequent positive developments can be directly attributed to the Scottish political arena in general and to devolution in particular. Of course, the answer must be a matter of judgement, since it is not possible to know what would have transpired without devolution. Nevertheless, this paper has identified an intensity of commitment to the educational needs of a potentially marginalized group which appears to have been facilitated by the prominence of education generally within the business of the Parliament ${ }^{7}$.

The second proposition is concerned with whether there is any evidence of improvements in the education of looked after children and young people. The rather unsatisfactory, but realistic, answer is that there is none, or very little so far. The attainment statistics for care leavers are beginning to show marginal improvements but we need a longer timescale and much more detailed information to be sure. And in any case the statistics give a skewed impression of the achievements of looked after children as a group. We need to know more about the educational experiences of different categories and age groups of looked after children and young people. We also need to know more about efforts to encourage reading for pleasure with young children and about work in reading and maths recovery with older looked after children. We need to know about softer indicators, such as confidence and resilience, as well as about attainment. The research commissioned by the Executive in relation to the varied pilot projects they have funded should provide some answers but we need to be patient until this is reported in 2008. The network of further education colleges in Scotland, which means that virtually everyone has easy access to a college (Raab and Davidson, 1998), means that it is very likely that a proportion of young people in the NEET group (not in employment,

\footnotetext{
${ }^{7}$ For example, see A Manifesto for Children Looked After Away from Home at: http://www.sircc.strath.ac.uk/publications/Manifesto_of_looked_after_children.pdf.
} 
education and training), in which care leavers are said to be disproportionately represented (Scottish Executive, 2005b), will access FE courses in adulthood, and there is a need for research to investigate this possibility.

Finally, the third proposition relates to whether there is the potential for improvement. Again, the answer is a matter of judgement. The modest improvements which followed the publication of the Learning with Care report would not lead to an optimistic outlook but the climate within which the Looked after children \& young people: We can and must do better report is set feels more sophisticated, more supportive and more emphatic in its expectations of the young people themselves, and the professionals paid to support them. In the words of the report's preface: 'Second best is not good enough for Scotland's looked after children and young people' (ibid., p.7). 


\section{References}

Adams, F, Discipline in Scottish schools: A survey of teachers' views, Edinburgh: General Teaching Council for Scotland, 2005. Available online at: http://www.gtcs.org.uk/nmsruntime/saveasdialog.asp?IID=1057\&sID=1511.

Aldgate, J, \& McIntosh, M, Looking after the family: A study of children looked after in kinship care in Scotland, Edinburgh: Social Work Inspection Agency, 2006. Available online at: http://www.scotland.gov.uk/Publications/2006/06/07132800/0.

Borland, M, Pearson, C, Hill, M, \& Bloomfield, I, Education and care away from home: A review of policy, practice and research, Edinburgh: Scottish Council for Research in Education, 1998.

Bullock, R, Little, M \& Millham, S, Going home: The return of children separated from their families, Aldershot: Dartmouth Publishing Company, 1993.

Connelly, G, Developing quality indicators for learning with care, Scottish Journal of Residential Child Care, 2 (2), 69-78, 2003.

DfES (Department for Education and skills), Care matters: Transforming the lives of children and young people in care, London: DfES, 2006. Available online at: http://www.dfes.gov.uk/publications/carematters/index.shtml.

Dixon, J, \& Stein, M, Still a bairn: Throughcare and aftercare services in Scotland, Edinburgh: Scottish Executive. Available online at: http://www.scotland.gov.uk/Publications/2002/06/14924/7628. 
Francis, J, Thomson, G, O, B, \& Mills, S, The quality of the educational experience of children in care, Edinburgh: University of Edinburgh.

Furnivall, J and Hudson, B, The learning with care training materials, Scottish Journal of Residential Child Care, 2 (2), 63-68, 2003.

Happer, H, McCreadie, J, and Aldgate, J, Celebrating success: What helps looked after children succeed, Edinburgh: SWIA, 2006. Available online at: http://www.scotland.gov.uk/Publications/2006/06/07121906/0.

HMI (Her Majesty's Inspectors of Schools) and SWSI (Social Work Services Inspectorate), Learning with care: The education of children looked after away from home by local authorities. Edinburgh: HMI and SWSI, 2001. Available online at: http://www.scotland.gov.uk/library3/education/lacr-00.asp.

Hare, A and Bullock, R, Dispelling misconceptions about looked after children, Adoption \& Fostering, 30 (4), 26-35, 2006.

Keating, M and Cairney, P, A new elite? Politicians and civil servants in Scotland after devolution, Parliamentary Affairs, 59 (1), 43-59, 2006.

McRae, J, Children looked after by local authorities: The legal framework. Edinburgh: SWIA, 2006. Available online at: http://www.scotland.gov.uk/Publications/2006/06/07104155/0.

Maclean, K and Gunion, M, Learning with care: The education of children looked after away from home by local authorities, Adoption \& Fostering, 27 (2), 20-31, 2003. 
O'Hagan, P, A different class? Educational attainment: The views and experiences of looked after young people. Glasgow: Who Cares? Scotland, 2003. Available online at: http://www.scotland.gov.uk/Publications/2004/10/20118/45456.

Raab, G and Davidson, K, Distribution of further education in Scotland, Edinburgh: Scottish Executive Education Department, 1998.

SWIA (Social Work Inspection Agency), Extraordinary lives: creating a positive future for looked after children and young people in Scotland, Edinburgh: SWIA, 2006. Available online at: http://www.scotland.gov.uk/Publications/2006/08/07134204/0.

Scottish Executive, Special schoolbooks fund for kids in care: News release SE4195/2001, 2001. Available online at: http://www.scotland.gov.uk/pages/news/2001/10/SE4195.aspx.

Scottish Executive, Better deal needed for looked after children: News release SE5139/2002, 2002. Available online at: http://www.scotland.gov.uk/pages/news/2002/01/SE5139.aspx.

Scottish Executive, Improving education of looked after children: News release SEed200/2003, 2003. Available online at:

http://www.scotland.gov.uk/pages/news/2003/02/SEed200.aspx.

Scottish Executive, Further steps to improve education for children in care: News release 2004/10/26103049, 2004. Available online at:

http://www.scotland.gov.uk/News/Releases/2004/10/26103049.

Scottish Executive, Getting it right for every child: Proposals for action, Edinburgh: Scottish Executive, 2005a. Available online at:

http://www.scotland.gov.uk/Publications/2005/06/20135608/56098. 
Scottish Executive, Literature review of the NEET group, Edinburgh: Scottish Executive, 2005b. Available online at:

http://www.scotland.gov.uk/Publications/2005/10/27175707/57078.

Scottish Executive, Looked after children \& young people: We can and must do better, Edinburgh: Scottish Executive, 2007. Available online at:

http://www.scotland.gov.uk/Publications/2007/01/15084446/0.

Sergeant, H, Handle with care: An investigation into the care system, London: Centre for Young Policy Studies, 2006.

Vincent, S, Looking after children in Scotland: Good parenting, good outcomes: Report on file audit of local authorities' use of looking after children materials, Edinburgh: Scottish Executive, 2004. Available online at:

http://www.scotland.gov.uk/Publications/2004/06/19439/38253. 
Table 1

Percentage of 16 and 17 year-old care leavers in Scotland with one or more 'Level 3' qualifications

\begin{tabular}{|l|c|c|l|c|c|c|}
\hline & $\begin{array}{l}\text { Number of } \\
\text { care leavers }\end{array}$ & $\begin{array}{l}\text { Looked after } \\
\text { 'at home' }\end{array}$ & $\begin{array}{l}\text { Looked after } \\
\text { 'away from } \\
\text { home' }\end{array}$ & $\begin{array}{l}\text { Total, all } \\
\text { looked after }\end{array}$ & $\begin{array}{l}\text { Gained both } \\
\text { English and } \\
\text { mathematics at } \\
\text { this level or } \\
\text { above (looked } \\
\text { after) }\end{array}$ & $\begin{array}{l}\text { Gained both } \\
\text { English and } \\
\text { mathematics } \\
\text { at this level } \\
\text { or above (all } \\
\text { pupils) }\end{array}$ \\
\hline $2003-04$ & 1146 & $35 \%$ & $52 \%$ & $42 \%$ & $27 \%$ & $91 \%(\mathrm{a})$ \\
\hline $2004-05$ & 980 & $37 \%$ & $55 \%$ & $45 \%$ & $30 \%$ & $90 \%(\mathrm{~b})$ \\
\hline $2005-06$ & 1267 & $45 \%$ & $57 \%$ & $50 \%$ & $34 \%$ & $91 \%(\mathrm{c})$ \\
\hline
\end{tabular}

Notes

1. Source: Scottish Executive: http://www.scotland.gov.uk/Publications/2006/12/08105227/0

2. 'Level 3' refers to the Scottish Credit and Qualifications Framework (see http://www.scqf.org.uk) a system of attainment from Access 1 (level 1) to Doctorate (level 12). Level 3 qualifications include the foundation level of Standard Grade (equivalent to GCSE) and similar qualifications accredited by the Scottish Qualifications Authority (see http://www.sqa.org.uk)

3. Sources for final column: Scottish Executive:

(a) http://www.scotland.gov.uk/Publications/2004/09/19971/43529

(b) http://www.scotland.gov.uk/Publications/2005/09/2393330/33314

(c) http://www.scotland.gov.uk/Publications/2006/09/14140034/0 


\section{Table 2}

Exclusions from school of looked after children in Scotland 1999-00 to 2005-06

\begin{tabular}{|l|c|c|c|}
\hline & Total, all exclusions & $\begin{array}{l}\text { Total exclusions of looked } \\
\text { after children/young people }\end{array}$ & $\begin{array}{l}\text { Rate per 1,000 looked } \\
\text { after children aged 5-15 }\end{array}$ \\
\hline $1999-00$ & 38769 & 3141 & 390 \\
\hline $2000-01$ & 38656 & 1339 & 172 \\
\hline $2001-02$ & 37442 & 1235 & 227 \\
\hline $2002-03$ & 36496 & 1819 & 253 \\
\hline $2003-04$ & 38912 & 1396 & 339 \\
\hline $2004-05$ & 41974 & 2579 & 337 \\
\hline $2005-06$ & 42990 & 3046 & \\
\hline
\end{tabular}

\section{Notes}

1. Source: http://www.scotland.gov.uk/Publications/2007/01/30100624/0.

2. The figures refer to 'cases' of exclusion and not to numbers of children, as one child may be excluded on more than one occasion during a year.

3. The overall rate of exclusion from local authority primary, secondary and special schools in Scotland in 2005-06 was 60 per 1,000 pupils. There was considerable variation in the rates of exclusion between local authorities, ranging from 6 per 1,000 to 122 per 1,000. The overall rate for 'non-looked after' pupils in 2005-06 was 55 per 1,000. 